\title{
PRELIMINARY STUDY ON THE USE OF METEOROLOGICAL DATA TO CALCULATE CROP WATER REQUIREMENTS FOR WHEAT IN TOSHKA.
}

Soliman, E. M. ${ }^{(1)}$; Fares, W. M. ${ }^{(2)}$ and Meleha, A. A. ${ }^{(3)}$

1) Institute of Environmental studies and Research, Ain Shams University

2) Central Laboratory for Design and Statistical Analysis, Agriculture Research Center. 3) Water Studies and Research Complex, National Water Research Center.

\begin{abstract}
The present investigation was carried out at the experimental Farm, Water Studies and Research Complex (WSRC) station, National Water Research Center, Toshka,

Where as use of the wheat crop in the study of the integrated management of water and agriculture as well as an assessment of reference evapotranspiration (ETo) within the meteorological data by using computer programs.

where transactions of different irrigation treatments $(60,80,100,120 \%)$ of crop evapotranspiration (ETC) with the note that was calculated the amounts of calculated based upon the daily (ETo) measured using penman-monteith method with in every day the irrigation process were carried out at 8 am in the morning.

When the comparison between classes (Egypt 1, Egypt 2) varieties in both seasons under the different irrigation treatments was not significant between varieties in all levels as experiments proved that both ( plant height ,spike length ,number of grains/spike, biological weight, grain weight, 1000grain weight, day of heading, number of spikelet's and straw yield ) did not give significant results between (Egypt1, Egypt2) varieties and give a significant results between all different irrigation treatments (60, 80,100,120\%) (ETC) as well as give results in Super Absorbent Polymers (SAP) (hydrogel treatment).

-The height wheat crop productivity to (Egypt1, Egypt2) varieties used $(120 \%)$ ETC treatment and the highest crop productivity was added the
\end{abstract}


Hydrogel as a (SAP), so this method should be used if there is no problem in irrigation water because it increases productivity.

-The lowest wheat crop productivity to (Egypt1, Egypt2) varieties used (60\%) ETC treatment so this method should be applied if we have problem in irrigation to save water.

-The reduction of irrigation water is one of the most important strategies now to face the water scarcity problem accordinary.It can reduce the small proportion of production with reducing irrigation water ratio up to $20-40 \%$ from water requirements as ashowed in the experiment to could be a good decision toward saving more water to irrigate more land and achieve the difficult equation which close the gap between production and demand and water scarcity conditions.

Keywords: meteorological data, Toshka, wheat, crop water requirements.

\section{INTRODUCTION}

The increase of agricultural production and the reduction of risks that retard development are a fundamental goal emphasized by the agricultural strategies, but how it is achieved?!

Especially that the Egyptian farmer does not find a link with the researchers and decision-makers carring out the researches, that incur more costs, time and effort to reach the positive results.

In this frame, we have tried to shed light on the importance of meteorology and their impact on the agricultural sector and the optimized application of Climatic Data monitored by the agricultural meteorological stations and that will monitor agricultural weather factors such as air temperature, soil temperature, relative humidity, solar radiation, rainfall, evaporation and transpiration (Eid, 1994).

(Eid et al 1999) explained that the weather elements have impact on agricultural operations where these elements can reflect a complete picture 
about atmosphere, optimum sowing dates for each crop, scheduling irrigation of cultivated crops, the most appropriate sowing rates, harmful effect of weather on crops and also the occurrence and places of frost.

Egypt is one of the countries that has limited water resources, which require study and accurately estimate water requirements for different crops. Egyptian desert is suffering from water poverty and hot arid climate as well as poor agricultural soil in nutrients and which is more evident in Toshka. So, we can fostulate a question: can we use software programs in the integrated crop management? The answer is yes, but how?

Using one of the programs made to calculate crop water requirements such as cropwat program, which aims to calculate the daily water requirement or scheduling irrigation for the growing season.

Sustainable agriculture uses the principles of ecology. It is defined as "an integrated system of plant and animal production practices that continues over a long period to meet the humanitarian needs of food, clothing, improving the quality of the environment, optimize the use of existing resources in the fields and develop the level of life for farmers and society as a whole.

The aim of the current study is to manage climate resources by analyzing climate data in the study region for the integrated management of soil and water for sustainable agriculture through the rationalization of water consumption to maximize the productivity available and to achieve agricultural development in Toshka. 


\section{MATERIALS AND METHODS}

From the previous presentation about integrated management of water and agriculture it is clear that:

- The use of sprinkler irrigation system has been more suitable for wheat than other alternative irrigation systems.

- More metrological data have been collected from Toshka weather station during the period (from 2008 to 2013). The suitable irrigation conditions were found to be in the early morning as shown in table (1) where the minimum temperature, minimum wind velocity and high humidity are convenient with irrigation. 
Table(1): Hourly averages of maximum temperature (T max), minimum temperature ( $\mathrm{T}$ min), relative humidity (Rh) and wind speed (Ws) during the average winter agricultural seasons from 2008 to 2013 for 24 hours at Toshka.

\begin{tabular}{|c|c|c|c|c||}
\hline $\begin{array}{c}\text { Item } \\
\text { Time }\end{array}$ & $\begin{array}{c}\text { Average } \\
\text { T max.(oC) }\end{array}$ & $\begin{array}{c}\text { Average } \\
\text { T min.(oC) }\end{array}$ & $\begin{array}{c}\text { Average } \\
\text { Rh (\%) }\end{array}$ & $\begin{array}{c}\text { Average } \\
\text { Ws ( m/s) }\end{array}$ \\
\hline \hline $01: 00$ & 17.8 & 16.3 & 34.3 & 2.4 \\
\hline $02: 00$ & 16.4 & 14.9 & 39.7 & 1.8 \\
\hline $03: 00$ & 15.3 & 13.8 & 43.6 & 1.8 \\
\hline $04: 00$ & 14.9 & 13.6 & 43.8 & 1.6 \\
\hline $05: 00$ & 13.7 & 13.5 & 45 & 1.7 \\
\hline $06: 00$ & 13.3 & 13 & 47.4 & 1.7 \\
\hline $07: 00$ & 13 & 12.4 & 50.7 & 1.8 \\
\hline $08: 00$ & 13.1 & 12.4 & 52 & 1.4 \\
\hline $09: 00$ & 15.4 & 14.3 & 50.3 & 1.6 \\
\hline $10: 00$ & 19.9 & 16.7 & 41.7 & 2.7 \\
\hline $11: 00$ & 21.3 & 20.9 & 38 & 3.4 \\
\hline $12: 00$ & 23.7 & 23.2 & 34.9 & 2.8 \\
\hline $13: 00$ & 24.9 & 25 & 30.2 & 3.5 \\
\hline $14: 00$ & 26.1 & 26 & 27.6 & 3.3 \\
\hline $15: 00$ & 28.3 & 26.5 & 23.9 & 3.2 \\
\hline $16: 00$ & 28.8 & 27 & 22.4 & 3.2 \\
\hline $17: 00$ & 28.1 & 27.1 & 22.8 & 2.2 \\
\hline $18: 00$ & 27.7 & 25.8 & 22.6 & 2.6 \\
\hline $19: 00$ & 26.2 & 22.6 & 28.6 & 2.2 \\
\hline $20: 00$ & 23.1 & 21 & 36.6 & 1.7 \\
\hline $21: 00$ & 21.8 & 19.2 & 43.4 & 1.4 \\
\hline $22: 00$ & 20.1 & 18.5 & 43.7 & 2 \\
\hline $23: 00$ & 19.7 & 18.8 & 39.6 & 2 \\
\hline $00: 00$ & 19 & 18.9 & 39.6 & 2.1 \\
\hline & & & & \\
\hline
\end{tabular}

Experimental Study: The present investigation was carried out at the experimental Farm, Water Studies and Research Complex(WSRC) station, National Water Research Center, Toshka-Abo Simbel City, Aswan, Egypt 
J. Environ. Sci.

Institute of Environmental Studies and Research - Ain Shams University

which is located at latitude of $22 \mathrm{o}, 24^{\prime} .11^{\prime} \mathrm{N}$ longitude of $31 \mathrm{o}, 35^{`} .43^{`} \mathrm{E}$ and of altitude $188 \mathrm{~m}$ during the two successive growth seasons of 2013/2014 and 2014/2015. The conducted experiment aimed at studying use of meteorological data in the integrated management of soil and water for sustainable agriculture in Toshka.

These experiments aimed to study the use of meteorological data in the integrated management of soil and water for sustainable agriculture in Toshka by using wheat crop in the study.

The water use efficiency of wheat crop was measured for these crops which have been irrigated by ground water resource (a deep well).

Where the use of the wheat crop in the study of the integrated management of water and agriculture as well as an assessment of reference evapotranspiration (ETo) within the meteorological data used computer programs and used the split plot in the experience were the irrigation levels arranged in the main plots while the subplots were randomly assigned to tested cultivars.

Grain rate was $60 \mathrm{~kg} / \mathrm{fed}$ Grains were sown on the 18th of November in both seasons, designed system testing sectors full random number five plots in all tests where transactions of different irrigation treatments (60, $80,100,120 \%$ ) of crop evapotranspiration (ETC) under sprinkler irrigation system with a plot area of $10 \mathrm{~m} \mathrm{2}$, with the note that was calculated the amounts of calculated based upon the daily (ETo) measured using penmanmonteith method with in every day during the irrigation process were carried out at ( $8 \mathrm{am}$ ) in the morning. 
Studying the response of the wheat crop varieties (Egypt 1, Egypt 2) showed exposure to water stress during the growing period as well as (Hydrogel) for innovative water serving technique for optimizing crop yield at a rate of $(6.5 \mathrm{~kg} / \mathrm{fed})(150 \mathrm{gm} / 100 \mathrm{~m} 2)$ where added in the second experiment through mixed polymer with the soil to increase the soil retain water efficiency.

In the first season experiment 2013/2014 where the comparison between different irrigation treatments $(60,80,100,120 \%)$ of crop evapotranspiration (ETC) under sprinkler irrigation system and the results between all different irrigation treatments for (Egypt1, Egypt2) varieties were significant.

In the second season $2014 / 2015$, another factor was added in addition to the basic experience in the previous season in order to confirm that the results between all different water levels and accurately were significant, as experiments proved that the results were significantly not only with different water levels without adding other factors adding but also after adding the other factor in the experiment (hydrogel).

When the comparison between classes (Egypt 1, Egypt 2) varieties in both seasons under the different irrigation treatments was not significant between varieties in all levels where experiments proved that both plant height ,spike length ,number of grains/spike, spike weight, biological weight, grain weight, 1000-grain weight, day of heading, number of spikelet's did not give significant results between (Egypt1, Egypt2) varieties and give a significant results between all different irrigation treatments (60, 80,100,120\%) (ETC) as well as give results in Hydrogel treatment. 
Wheat experiments.: In this section, the experimental design and agricultural treatment will be discussed as a follow:-

Experimental design.: The system of sectors testing had design in five full random plots in all tests where transactions of different irrigation treatments $(60,80,100,120 \%)$ of crop evapotranspiration (ETC) under sprinkler irrigation system with a plot area of $10 \mathrm{~m} 2$, with the note that was calculated the amounts of calculated based upon the daily (ETo) measured using penman-monteith method with in every day during carried out the irrigation process were carried out at 8 am in the morning.

A field experiment in wheat were carried out in split plot design with five replication ( R1, R2, R3, R4, R5 ) and four treatments expressed as (60, 80,100,120\%) of crop evapotranspiration (ETC) respectively for Egypt 1, Egypt 2 varieties under sprinkler irrigation system.

The bounded was selected with buffer zone (10 m width) to avoid the interaction between sprinklers. The plot units were with an area of $100 \mathrm{~m} 2$ (almost 1/40 fed). The sprinkler system is constant (Brass impact rotate, Rain Baird, USA) with lateral line length of $72 \mathrm{~m}$ and $12 \mathrm{~m}$ space. Each line has 6 rotate sprinklers about $1.0 \mathrm{~m}$ above the ground with a flow rate of 1.2-1.4 m3 / hour at 2-3 bars.

The agricultural treatment.Irrigation: Irrigation treatments were started after completion of germination, 14 days after planting. Wheat plants were irrigated daily at 8:00 o'clock in the morning using the calculated amount of water based on ETo and crop factor for each growth period (FAO 56) as summarized in table 3.4. The amounts of irrigation water were varied 
according to the variation in climate demands of each growth period. The irrigation times were varied according to the amounts of irrigation water and discharge rate. In the winter seasons of 2013/2014 and 2014/2015, wheat seeds (Egypt1, Egypt2 varieties) were sown on November 18 in both seasons, with a rate of $60 \mathrm{Kg} /$ fed under sprinkler irrigation system. Wheat plants were harvested on March 30 and March 31 in the first and second seasons for (Egypt1, Egypt2 varieties), respectively. All agriculture practices were applied at the recommendations set by the Ministry of Agriculture. Nitrogen, phosphorus and potassium fertilizers were added according to the recommended levels. Nitrogen was applied as ammonium nitrate $(33.5 \% \mathrm{~N})$ at a level of $100 \mathrm{Kg} \mathrm{N} / \mathrm{fed}$. This amount was divided into 4 equal doses, which were applied before the flowering. Phosphorus in the form of super phosphate (15.5\% P2O5) was added at a level of $200 \mathrm{~kg} / \mathrm{fed}$., in one dose before planting. Potassium in the form of potassium sulphate $(48 \% \mathrm{~K} 2 \mathrm{O})$ was added in two equal portions at a level of $100 \mathrm{~kg} / \mathrm{fed}$ at the late growth stage.

\section{Calculation of irrigation water requirement:}

2.1 Reference evapotranspiration (ETo): The reference ET0 was estimated, using available meteorological data of Toshka station. The water model (Zazueta and Smajstrala 1984 ) was used to calculate reference ET0 by Modified Penman, Jensen and Haise, Doorenbos \& Pruitt and pan evaporation, while CROPWAT model -which using in the study- was used to calculate (Penman Monteith Smith 1991).

The Penman-Monteith (PM) method is the most recommended method for estimating reference evapotranspiration (ETo). The PM equation requires 
several parameters to be available, either measured or computed.( Alazba 2001).

2.2 FAO Penman-Monteith equation (Allen et al., 1998): The panel of FAO experts recommended the adoption of the Penman-Monteith combination method as a new standard for reference evapotranspiration and advised on procedures for calculation of the various parameters. By defining the reference crop as a hypothetical crop with an assumed height of $0.12 \mathrm{~m}$ having a surface resistance of $70 \mathrm{~s} \mathrm{~m}-1$ and an albedo of 0.23 , closely resembling the evaporation of an extension surface of green grass of uniform height, actively growing and adequately watered. The developed FAO Penman-Monteith method overcomes shortcomings of the previous FAO Penman method and provides values more consistent with actual crop water use data worldwide.

\section{The equation is as follows:}

$$
E T_{0}=\frac{0.408 \Delta\left(R_{n}-G\right) \gamma \frac{900}{T+273} u_{2}\left(e_{s}-e_{a}\right)}{\Delta+\gamma\left(1+0.34 u_{2}\right)}
$$

Where: $\mathrm{ET}_{0}=$ Reference evapotranspiration $\left(\mathrm{mm}_{\text {day }}{ }^{-1}\right)$.

$R_{n}=$ Net radiation at the crop surface $\left(\mathrm{MJ} \mathrm{m}^{-2}\right.$ day $\left.{ }^{-1}\right)$.

$\mathrm{G}=$ Soil heat flux density $\left(\mathrm{MJ} \mathrm{m}^{-2}\right.$ day $\left.^{-1}\right)$.

$\mathrm{T}=$ Mean daily air temperature at $2 \mathrm{~m}$ height $\left({ }^{\circ} \mathrm{C}\right)$.

$\mathrm{u}_{2}=$ Wind speed at $2 \mathrm{~m}$ height $\left(\mathrm{m} \mathrm{s}^{-1}\right)$.

$\mathrm{e}_{\mathrm{s}} \quad=$ Saturation vapour pressure $(\mathrm{kPa})$.

$\mathrm{e}_{\mathrm{a}}=$ Actual vapour pressure $(\mathrm{kPa})$.

$\mathrm{e}_{\mathrm{s}}-\mathrm{e}_{\mathrm{a}}=$ Saturation vapour pressure deficit $(\mathrm{kPa})$.

$\Delta=$ Slope vapour pressure curve $\left(\mathrm{kPa}^{\circ} \mathrm{C}^{-1}\right)$.

$\gamma=$ Psychometric constant $\left(\mathrm{kPa}^{\circ} \mathrm{C}^{-1}\right)$. 
2.3 Crop evapotranspiration (ETc). (Allen, 1998). Crop evapotranspiration depends on many factors, weather parameters, crop characteristics, management and environment aspects are factors affecting evaporation and transpiration. According to (Allen et al. 1998), the ETC is calculated according to the following equation:-

$$
E T_{c}=E T_{\mathrm{O}} \times K_{C}
$$

Where:- ETc $=$ Crop evapotranspiration. ET0 $=$ Reference evapotranspiration .

$$
\mathrm{Kc}=\text { Crop coefficient. }
$$

2.4.Crop coefficient (Kc): The Crop coefficient reflects the crop characteristics on the crop evapotranspiration. The $\mathrm{Kc}$ is calculated as the dimensionless ratio of the ETc and the ET0 . as follow (Allen et al., 1998)

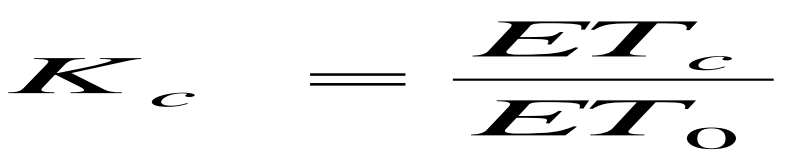

Where: $\mathrm{ETc}=$ Actual crop consumptive use measured from the field in $\mathrm{mm} /$ day.

ET0 $=$ Reference evapotranspiration $(\mathrm{mm} /$ day $)$

25 Irrigation water use efficiency (IWUE): The irrigation water use efficiency (IWUE) values were calculated as follows: (Vits, 1965).

$$
I W U E=\frac{\text { Grain or Seed yield }(\mathrm{Kg} / \mathrm{fed} .)}{\text { Irrigation water requirements }\left(\mathrm{m}^{3} / \mathrm{fed} .\right)}
$$


The amount of required irrigation water for different irrigation systems was calculated using the area of different irrigation systems as follow:

$\mathrm{IR}=$ ETcrop $\times \mathrm{A}$

\section{Where: IR: irrigation water required (L).}

A: The plot area $(0.25 \mathrm{fed})$.

Irrigation water applied for treatments $60 \% \mathrm{ETc}=\mathrm{IR} \times 0.6(\mathrm{~L})$.

Irrigation water applied for treatments $80 \% \mathrm{ETc}=\mathrm{IR} \times 0.8 .(\mathrm{L})$.

Irrigation water applied for treatments $100 \% \mathrm{ETc}=\mathrm{IR} \times 1.0(\mathrm{~L})$.

Irrigation water applied for treatments $120 \% \mathrm{ETc}=\mathrm{IR} \times 1.2 .(\mathrm{L})$.

\section{RESULTS AND DISCUSSIONS}

Irrigation water is one of the most important inputs in crop production. The arid regions suffer from water shortage due to its scarcity and irregular distribution. The management of water resources in arid regions requires good knowledge and great skills especially in the case of limited water supply. Adding too much or too little water may cause a serious damage for crops; therefore water requirement must be carefully determined. Water use for agricultural crops is important for adequate water management in arid and semiarid areas where irrigation is necessary and water is limited and expensive. Egypt is forced to implement serious efforts towards the equilibrium between its limited water supply and demand.

Where the use of the wheat crop in the study of the integrated management of water and agriculture as well as an assessment of reference evapotranspiration (ET0) within studied the meteorological data of Toshka 
weather station, which were used in the calculated, during the growth seasons are present in Table 2 by using computer programs.

Table (2): Average monthly meteorological data of Toshka weather station during the growth seasons

\begin{tabular}{|c|c|c|c|c|c|c|c|c|}
\hline \multicolumn{9}{|c|}{ 2013/2014 Winter Season } \\
\hline \multirow[b]{2}{*}{$\begin{array}{l}\text { Element } \\
\text { Month }\end{array}$} & \multirow[b]{2}{*}{$\begin{array}{c}\text { Rain } \\
\text { mm/da } \\
\mathbf{y}\end{array}$} & \multirow[b]{2}{*}{$\begin{array}{c}\text { W.S } \\
(\mathrm{m} / \mathrm{sec} \\
)\end{array}$} & \multirow{2}{*}{\begin{tabular}{|c} 
Sunshin \\
e \\
hours/d \\
ay
\end{tabular}} & \multirow[b]{2}{*}{$\begin{array}{l}\text { RH } \\
(\%)\end{array}$} & \multicolumn{2}{|c|}{ Temperatur } & \multirow[b]{2}{*}{$\begin{array}{c}\text { SR } \\
\text { (watt/m2 } \\
/\end{array}$} & \multirow{2}{*}{\begin{tabular}{|c} 
ET0 \\
$(\mathrm{mm})$ \\
Penman- \\
Monteith
\end{tabular}} \\
\hline & & & & & $\begin{array}{l}\text { Min } \\
\text { (oc) }\end{array}$ & $\begin{array}{c}\text { Max } \\
(\text { oc) }\end{array}$ & & \\
\hline November & 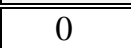 & 2.5 & 10.9 & 32.93 & 15.51 & 31.23 & 160.79 & 5.55 \\
\hline December & 0 & 2.44 & 10.6 & 36.33 & 10.78 & 26.81 & 145.85 & 4.54 \\
\hline January & 0 & 2.7 & 10.7 & 36.5 & 16.44 & 24.57 & 143.8 & 4.77 \\
\hline February & 0 & 2.99 & 11.17 & 25.2 & 11.12 & 28.18 & 189.12 & 6.19 \\
\hline March & 0 & 3.09 & 11.7 & 35.23 & 12.99 & 24.22 & 222.65 & 5.98 \\
\hline \multicolumn{9}{|c|}{ 2014/2015 Winter Season } \\
\hline Novembe & 0 & 2.36 & 10.9 & 32.6 & 12.23 & 28.29 & 163.62 & 5.29 \\
\hline December & 0 & 2.54 & 10.6 & 35.78 & 9.69 & 26.02 & 146.17 & 4.54 \\
\hline January & 0 & 2.20 & 10.7 & 41.1 & 8.4 & 24.2 & 157.8 & 4.08 \\
\hline February & 0 & 2.60 & 11.17 & 30.8 & 12.5 & 28.1 & 176 & 5.68 \\
\hline March & 0 & 3.10 & 11.7 & 20.9 & 13.5 & 30.3 & 223.3 & 7.38 \\
\hline
\end{tabular}

(RH): relative humidity (WS): wind speed (SR) : solar radiation

1. Calculation of irrigation water requirement: Irrigation was carried on every day. The amounts of irrigation water add to different irrigation regimes during the growth seasons and some climatic data of Toshka weather station were used in the calculated, during the growth seasons are present in Tables 3,4 by using computer programs presented. 
J. Environ. Sci.

Institute of Environmental Studies and Research - Ain Shams University

Table (3): Total amount of irrigation water of wheat crop season 2013/14 in different irrigation regimes experiment calculated based upon Et0.

\begin{tabular}{|c|c|c|c|c|c|c|c|c|c|c|}
\hline \multirow{3}{*}{ Growing Period } & \multicolumn{10}{|c|}{ Growing Season 2013/14 } \\
\hline & \multirow{2}{*}{$\begin{array}{c}\mathbf{E T}_{\mathbf{0}} \\
\mathbf{m m} / \\
\text { perio } \\
\text { d }\end{array}$} & \multirow{2}{*}{$\begin{array}{c}\mathbf{E T}_{\mathbf{o}} \\
\mathbf{~ m m} / \\
\text { day }\end{array}$} & \multirow{2}{*}{$\mathbf{K}_{\mathbf{c}}$} & \multirow{2}{*}{$\begin{array}{c}\mathbf{E T}_{\mathbf{c}} \\
\mathbf{m m} / \\
\text { day }\end{array}$} & \multirow{2}{*}{$\begin{array}{l}\text { I.E } \\
(\%)\end{array}$} & \multirow{2}{*}{ L.R } & \multicolumn{4}{|c|}{$\begin{array}{c}\text { CWR } \\
\text { (mm/ period) }\end{array}$} \\
\hline & & & & & & & $60 \%$ & $80 \%$ & $100 \%$ & $\begin{array}{c}120 \\
\%\end{array}$ \\
\hline 18-27/11/2013 & 54.67 & 5.47 & 0.3 & 16.40 & 0.75 & 1.2 & 8.86 & 11.81 & 14.76 & 17.71 \\
\hline $28-7 / 11 / 2013$ & 51.73 & 5.17 & 0.3 & 15.52 & 0.75 & 1.2 & 8.38 & 11.17 & 13.97 & 16.76 \\
\hline $8-17 / 12 / 2013$ & 46.66 & 4.67 & 0.3 & 14.00 & 0.75 & 1.2 & 7.56 & 10.08 & 12.60 & 15.12 \\
\hline $18-27 / 12 / 2013$ & 42.53 & 4.25 & 0.46 & 19.56 & 0.75 & 1.2 & 10.56 & 14.09 & 17.61 & 21.13 \\
\hline $28-6 / 12 / 2013$ & 41.37 & 4.14 & 0.74 & 30.61 & 0.75 & 1.2 & 16.53 & 22.04 & 27.55 & 33.06 \\
\hline $7-16 / 1 / 2014$ & 40.91 & 4.09 & 1.02 & 41.73 & 0.75 & 1.2 & 22.53 & 30.04 & 37.56 & 45.07 \\
\hline $17-26 / 1 / 2014$ & 41.72 & 4.17 & 1.15 & 47.98 & 0.75 & 1.2 & 25.91 & 34.54 & 43.18 & 51.82 \\
\hline $27-4 / 1 / 2014$ & 45.54 & 4.55 & 1.15 & 52.37 & 0.75 & 1.2 & 28.28 & 37.71 & 47.13 & 56.56 \\
\hline $5-14 / 2 / 2014$ & 52.67 & 5.27 & 1.15 & 60.57 & 0.75 & 1.2 & 32.71 & 43.61 & 54.51 & 65.42 \\
\hline $15-24 / 2 / 2014$ & 62.16 & 6.22 & 1.15 & 71.48 & 0.75 & 1.2 & 38.60 & 51.47 & 64.34 & 77.20 \\
\hline $25-6 / 2 / 2014$ & 71.18 & 7.12 & 0.99 & 70.47 & 0.75 & 1.2 & 38.05 & 50.74 & 63.42 & 76.11 \\
\hline $7-16 / 3 / 2014$ & 74.22 & 7.42 & 0.71 & 52.70 & 0.75 & 1.2 & 28.46 & 37.94 & 47.43 & 56.91 \\
\hline $17-26 / 3 / 2014$ & 62.29 & 6.23 & 0.43 & 26.78 & 0.75 & 1.2 & 14.46 & 19.28 & 24.11 & 28.93 \\
\hline Total water & & & & & & & 280.90 & 374.53 & 468.16 & 561.79 \\
\hline
\end{tabular}

ET0): Reference evapotranspiration (Kc) Crop coefficient (ETC) Crop evapotranspiration :(I.E) : Irrigation efficiency (L.R) Lavement requirements (CWR): Crop water requirements. 
Table (4): Total amount of irrigation water of wheat crop season 2014/15 in different irrigation regimes experiment calculated based upon Et0

\begin{tabular}{|c|c|c|c|c|c|c|c|c|c|c|}
\hline \multirow{3}{*}{ Growing Period } & \multicolumn{10}{|c|}{ Growing Season 2014/15 } \\
\hline & \multirow{2}{*}{$\begin{array}{c}\mathbf{E T}_{0} \\
\mathbf{m m} / \\
\text { period }\end{array}$} & \multirow{2}{*}{$\begin{array}{c}\mathbf{E T}_{\mathbf{o}} \\
\mathbf{m m} / \\
\text { day }\end{array}$} & \multirow[t]{2}{*}{$\mathbf{K}_{\mathrm{c}}$} & \multirow{2}{*}{$\begin{array}{c}\mathbf{E T}_{\mathrm{c}} \\
\mathbf{m m} / \\
\text { day }\end{array}$} & \multirow[t]{2}{*}{ I.E $(\%)$} & \multirow[t]{2}{*}{ L.R } & \multicolumn{4}{|c|}{$\begin{array}{c}\text { CWR } \\
(\mathrm{mm} / \text { period })\end{array}$} \\
\hline & & & & & & & $60 \%$ & $80 \%$ & $100 \%$ & $120 \%$ \\
\hline $18-27 / 11 / 2014$ & 55.97 & 5.60 & 0.3 & 16.79 & 0.75 & 1.2 & 15.11 & 9.07 & 12.09 & 18.13 \\
\hline 28-7/11/2014 & 51.68 & 5.17 & 0.3 & 15.50 & 0.75 & 1.2 & 13.95 & 8.37 & 11.16 & 16.74 \\
\hline $8-17 / 12 / 2014$ & 46.52 & 4.65 & 0.3 & 13.96 & 0.75 & 1.2 & 12.56 & 7.54 & 10.05 & 15.07 \\
\hline $18-27 / 12 / 2014$ & 43.70 & 4.37 & 0.46 & 20.10 & 0.75 & 1.2 & 18.09 & 10.86 & 14.47 & 21.71 \\
\hline 28-6/12/2014 & 44.78 & 4.48 & 0.74 & 33.14 & 0.75 & 1.2 & 29.82 & 17.89 & 23.86 & 35.79 \\
\hline $7-16 / 1 / 2015$ & 46.91 & 4.69 & 1.02 & 47.85 & 0.75 & 1.2 & 43.06 & 25.84 & 34.45 & 51.68 \\
\hline $17-26 / 1 / 2015$ & 49.87 & 4.99 & 1.15 & 57.35 & 0.75 & 1.2 & 51.62 & 30.97 & 41.29 & 61.94 \\
\hline $27-4 / 1 / 2015$ & 54.29 & 5.43 & 1.15 & 62.43 & 0.75 & 1.2 & 56.19 & 33.71 & 44.95 & 67.43 \\
\hline $5-14 / 2 / 2015$ & 59.55 & 5.96 & 1.15 & 68.48 & 0.75 & 1.2 & 61.63 & 36.98 & 49.31 & 73.96 \\
\hline $15-24 / 2 / 2015$ & 64.25 & 6.43 & 1.15 & 73.89 & 0.75 & 1.2 & 66.50 & 39.90 & 53.20 & 79.80 \\
\hline $25-6 / 2 / 2015$ & 66.13 & 6.61 & 0.99 & 65.47 & 0.75 & 1.2 & 58.92 & 35.35 & 47.14 & 70.71 \\
\hline $7-16 / 3 / 2015$ & 61.85 & 6.19 & 0.71 & 43.91 & 0.75 & 1.2 & 39.52 & 23.71 & 31.62 & 47.43 \\
\hline $17-26 / 3 / 2015$ & 46.85 & 4.69 & 0.43 & 20.15 & 0.75 & 1.2 & 18.13 & 10.88 & 14.50 & 21.76 \\
\hline Total water & & & & & & & 291.1 & 388.1 & 485.1 & 582.1 \\
\hline
\end{tabular}

ET0): Reference evapotranspiration (Kc) Crop coefficient (ETC) Crop evapotranspiration : (I.E) : Irrigation efficiency (L.R) Lavement requirements (CWR): Crop water requirements.

Irrigation water use efficiency (IWUE): In irrigated agriculture in arid and semi-arid regions where water resources are limited and/or diminishing, and where rainfall is limited, crop water use efficiency (WUE) became of crucial and of important consideration. Even with using the newly developed irrigation systems that using different sources of energy and with resent 
increases in energy prices, have many farmers asking how to manage inputs to maximize efficiency of their water resources. Regardless of the situation, it's crucial that growers get the most out of every $\mathrm{cm}$ of available water, on the WUE is to be assessed to adopt the irrigation management practices that maximize the outcome of each unit of irrigation water (Vits 1965).

In this part of the present work, irrigation water use efficiency (IWUE) was calculated as a ratio between the total dry mater ( $\mathrm{kg}$ fed-1) and the amount of irrigation water used (m3 fed-1). Data presented in Tables 5 and 6 summaries the effects of the irrigation regimes on both varieties in both seasons, and their interaction on (IWUE) total dry matter produced by wheat plants grown in different irrigation treatments.

With increasing the amount of irrigation water from 60 to $120 \%$ ETc the IWUE decreased in both growth seasons. In 2013/14 growth season the high difference in IWUE of the 60 and $120 \%$ ETc treatments could be a direct result of losing some plants by bird attack as mentioned previously. In 2014/15, growth season the same happened therefore this explains the increase in IWUS with applying only $60 \%$ of the required irrigation water by crop $(\mathrm{ETc})$. The irrigation water use efficiency is increased as a direct result of reducing the accumulation of dry matter with a rate less than that of reducing the amount of irrigation water. (Simonne et al., 2006;Elmaloglou and Diamantopoulos, 2009;Elmaloglou and Diamantopoulos ,2007). 
Table (5): Yield and irrigation water use efficiency (IWUE) of sprinkler irrigated wheat crop grown in irrigation regimes to both varieties in 2013-14 season.

\begin{tabular}{|c|c|c|c|c|c|c|c|c|c|c|c|c|}
\hline \multirow{3}{*}{$\begin{array}{l}\text { Factor } \\
\text { Irrigation }\end{array}$} & \multicolumn{12}{|c|}{ Crop Water Requirements Season 2013-2014 } \\
\hline & \multicolumn{3}{|c|}{ Grain Yield (kg/fed) } & \multicolumn{3}{|c|}{$\begin{array}{l}\text { Irrigation Water Applied } \\
\qquad(\mathrm{m} 3 / \mathrm{fed})\end{array}$} & \multicolumn{3}{|c|}{$\begin{array}{c}\text { Crop Water Use } \\
\text { Efficiency }(\mathrm{kg} / \mathrm{m} 3)\end{array}$} & \multicolumn{3}{|c|}{\begin{tabular}{|c|}
$\begin{array}{c}\text { Irrigation Water } \\
\text { Use Efficiency } \\
(\mathrm{kg} / \mathrm{m} 3)\end{array}$ \\
\end{tabular}} \\
\hline & $\begin{array}{c}\text { Misr } \\
1 \\
\end{array}$ & $\begin{array}{c}\text { Misr } \\
2 \\
\end{array}$ & Mean & $\begin{array}{c}\text { Misr } \\
1 \\
\end{array}$ & $\begin{array}{c}\text { Misr } \\
2 \\
\end{array}$ & Mean & $\begin{array}{c}\text { Misr } \\
1 \\
\end{array}$ & \begin{tabular}{|c|} 
Misr \\
2 \\
\end{tabular} & Mean & \begin{tabular}{|c} 
Misr \\
1 \\
\end{tabular} & \begin{tabular}{|c} 
Misr \\
2 \\
\end{tabular} & Mean \\
\hline $60 \%$ & 1562.4 & 1360.8 & 1461.6 & 1679.76 & 1679.76 & 1679.76 & 0.93 & 0.81 & 0.87 & 0.7 & 0.59 & 0.65 \\
\hline $80 \%$ & 1747.2 & 1722 & 1734.6 & 2073.01 & 2073.01 & 2073.01 & 0.84 & 0.83 & 0.84 & 0.63 & 0.61 & 0.62 \\
\hline $100 \%$ & 2066.4 & 2108.4 & 2087.4 & 2466.27 & 2466.27 & 2466.27 & 0.84 & 0.85 & 0.85 & 0.63 & 0.62 & 0.63 \\
\hline $120 \%$ & 2234.4 & 2259.6 & 2247 & 2859.52 & 2859.52 & 2859.52 & 0.78 & 0.79 & 0.79 & 0.59 & 0.58 & 0.59 \\
\hline Mean & 1902.6 & 1862.7 & 1882.65 & 2269.64 & 2269.64 & 2269.64 & 0.85 & 0.82 & 0.83 & 0.64 & 0.60 & 0.62 \\
\hline $\operatorname{LSD}_{0.05}$ & & $\begin{array}{l}64 \\
\mathrm{IX} V=\end{array}$ & $\begin{array}{l}\mathrm{V}=\mathrm{NS} \\
\mathrm{NS}\end{array}$ & 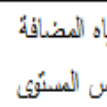 & لأن كيه لـ & لصنفى القُمة واحدة. & & & & & & \\
\hline
\end{tabular}

Table (6): Yield and irrigation water use efficiency (IWUE

\begin{tabular}{|c|c|c|c|c|c|c|c|c|c|c|c|c|c|}
\hline \multirow{2}{*}{\multicolumn{2}{|c|}{ Factor }} & \multicolumn{12}{|c|}{ Crop Water Requirements Season 2014-2015 } \\
\hline & & \multicolumn{3}{|c|}{ Grain Yield (kg/fed) } & \multicolumn{3}{|c|}{$\begin{array}{l}\text { Irrigation water applied } \\
(\mathrm{m} 3 / \mathrm{fed})\end{array}$} & \multicolumn{3}{|c|}{$\begin{array}{l}\text { Crop Water Use Efficiency } \\
\qquad(\mathrm{kg} / \mathrm{m} 3)\end{array}$} & \multicolumn{3}{|c|}{$\begin{array}{l}\text { Irrigation Water Use } \\
\text { Efficiency (kg/m3) }\end{array}$} \\
\hline Irrigation & Hydrogel & Misr 1 & Misr 2 & Mean & Misr 1 & Misr 2 & Mean & Misr 1 & Misr 2 & Mean & Misr 1 & Misr 2 & Mean \\
\hline \multirow{2}{*}{$60 \%$} & with & 1814,40 & 1755.60 & 1785.00 & 12225 & 12225 & 12225 & 1.48 & 1.44 & 1.46 & 1.11 & 1.08 & 1.10 \\
\hline & control & 1604.40 & 1545.60 & 1575.00 & 12225 & 12225 & 12225 & 1.31 & 1.26 & 1.29 & 0.98 & 0.95 & 0.97 \\
\hline & & 1709.40 & 1650.60 & 168000 & 12225 & 12225 & 12225 & 1.40 & 1.35 & 1.38 & 1.05 & 1.02 & 1.04 \\
\hline \multirow{2}{*}{$80 \%$} & with & 2016.00 & 212520 & 2070.60 & 1630 & 1630 & 1630 & 1.24 & 1.3 & 1.27 & 0.93 & 0.98 & 0.96 \\
\hline & control & 1822.80 & 1797.60 & 181020 & 1630 & 1630 & 1630 & 1.12 & 1.10 & 1.11 & 0.84 & 0.83 & 0.84 \\
\hline & & 1919.40 & 1961.40 & 1940.40 & 1630 & 1630 & 1630 & 1.18 & 1.2 & 1.19 & 0.89 & 0.91 & 0.90 \\
\hline \multirow{2}{*}{$100 \%$} & with & 2368.80 & 2394.00 & 2381.40 & 20375 & 20375 & 20375 & 1.16 & 1.17 & 1.17 & 0.87 & 0.88 & 0.88 \\
\hline & control & 217594 & 2192.40 & 2184.17 & 20375 & 20375 & 20375 & 1.01 & 1.08 & 1.05 & 0.80 & 0.81 & 0.81 \\
\hline & & 227237 & 229320 & 2282.78 & 20375 & 20375 & 20375 & 1.09 & 1.13 & 1.11 & 0.84 & 0.85 & 0.85 \\
\hline \multirow{2}{*}{$120 \%$} & with & 2528.40 & 2478.00 & 250320 & 2445 & 2445 & 2445 & 1.03 & 1.01 & 1.02 & 0.78 & 0.76 & 0.77 \\
\hline & control & 2310.00 & 229320 & 230160 & 2445 & 2445 & 2445 & 0.94 & 0.94 & 0.94 & 0.71 & 0.70 & 0.71 \\
\hline & & 241920 & 2385.60 & 2402,40 & 2445 & 2445 & 2445 & 0.99 & 0.98 & 0.98 & 0.75 & 0.73 & 0.74 \\
\hline \multicolumn{2}{|c|}{ Mean } & 2080.09 & 2072.7 & 2076.4 & 1833.75 & 1833.75 & 1833.75 & 1.16 & 1.16 & 1.16 & 0.88 & 0.87 & 0.88 \\
\hline \multicolumn{2}{|c|}{$\mathbf{L S D}_{0.05}$} & \multicolumn{3}{|c|}{ 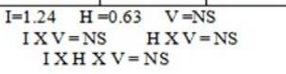 } & & & & & & & & & \\
\hline
\end{tabular}

Wheat yield and yield components.: Wheat is a major strategic food grain crop successfully grown under limited water conditions, Therefore its growth and high productivity depend mainly on the proper water management. The 
various crop development stages posses different sensitivities to moisture stress where time, duration and the degree of the stress all affect yield. Water management that maximize yield per unit of water consumed by plant are highly desired.

\section{A. Morphological characters:}

A.1.Dayes of heading: The data in table (7) show that days to heeding were significant affected by different irrigation treatments in both seasons to (Egypt1, Egypt2) varieties .The results reveal that a reduction in number of dates to heading recorded when plants under $(60,80 \%)$ Etc and where increase number of days to heading recorded when plants under $(100,120 \%)$ Etc and also effect was significant with (SAP) (hydrogel) treatment. The lowest values of day numbers were obtained at the (60\%) ETC treatment $(42.8,42.6)$ day in the first season and $(42.6,42.8)$ day in the second season. The highest values of day number obtained at the (120\%) ETC treatment (59, $59)$ day in the first season and $(59,59)$ day in the second season. In addition to the plants under (SAP) hydrogel treatment in the second season exerted a significant effect $(60.4,60.8)$ day to (Egypt1, Egypt2) varieties respectively. The results are in line with those obtained by (Abd El-Mogied ,1990).

A.2. Plant height (cm): The results in table (8) reveal that different irrigation treatments exerted significant effect on plant height in both seasons to (Egypt1, Egypt2) varieties. In general, the plants under $(60,80 \%)$ Etc was shorter than the plants under $(100,120 \%)$ Etc. Also increasing water levels and adding hydrogel increased plant height where a reduction in irrigation water to $(60,80 \%)$ Etc exerted a significant effect on plant height when 
compared with $(100,120 \%)$ Etc for (Egypt1, Egypt2) varieties as well as hydrogel treatment or when adding hydrogel. The lowest values of plants height obtained at the $(60 \%)$ ETC treatment $(85.2,86) \mathrm{cm}$ in the first season and $(84.2,85.2) \mathrm{cm}$ in the second season. The highest values of plants height were at the $(120 \%)$ Etc. treatment $(95.2,97.7) \mathrm{cm}$ in the first season and $(91.2,92) \mathrm{cm}$ in the second season. In addition to the plants under (SAP) hydrogel treatment in the second season exerted a significant effect (98.8, 97.8) $\mathrm{cm}$ to (Egypt1, Egypt2) varieties respectively. These results are in accordance with those obtained by (Hassaan, 2003; Golam and Goswami, 2004; Mohamed, 2007; Hefzy, 2009).

A.3. Spike length (cm): Data presented in table (9) and show that Irrigation treatments exerted a significant effect on Spike length in both seasons to (Egypt1, Egypt2) varieties. The lowest values of Spike length obtained at the (60\%) ETC treatment $(9.2,9.3) \mathrm{cm}$ in the first season and $(9.2,9.7) \mathrm{cm}$ in the second season. The highest values of Spike length obtained at the (120\%) ETC treatment $(12.1,11.4) \mathrm{cm}$ in the first season and $(11.9,12.2) \mathrm{cm}$ in the second season. In addition to the plants under (SAP) hydrogel treatment in the second season exerted a significant effect $(12.1,12.3) \mathrm{cm}$ to (Egypt1, Egypt2) varieties respectively. These results are in line with those obtained by Abd ElMogied, 1990; Mohamed and Tammam, 1999; Shivani et al,. 2001; and Mohamed, 2007).

\section{B. Yield and yield components}

B.1. No of spikes per square meter: The data in table (10) show that Irrigation treatments exerted a significant effect on Number of spikes / M2 in both seasons to (Egypt1, Egypt2) varieties. The lowest values of spikes 
number obtained at the $(60 \%)$ ETC treatment $(301,335.2)$ and $(331,324)$ in the first season and second season to (Egypt1, Egypt2) varieties respectively. The highest values of spikes number obtained at the (120\%) ETC treatment $(420,422.2)$ and $(417.8,423.4)$ in the same arrangement with confirm note the significant effect between water treatments and not significant effect between (Egypt1, Egypt2) varieties by using hydrogel treatment were obtained at the $(120 \%)$ ETC treatment $(452.4,453.4)$ respectively. These results are in agreement with those obtained by (Hassan,2003;Salem, 2005;Khalil, et al., 2006;Mohamed, 2007;Hefzy,2009).

B.2. Number of grains per spike: The results in table (11) indicate that Plants exposed to drought decreased number of grains / spike significantly in both seasons to (Egypt1, Egypt2) varieties. While in the (60\%) ETC treatment obtained the lowest number of grains $(44,46.2)(49.2,43.2)$ in the first season and second season to (Egypt1, Egypt2) varieties respectively. While in the $(120 \%)$ ETC treatment obtained the highest number of grains $(64.4,66.6)(65$, 63.2) in the same arrangement with confirm note the significant effect between water treatments and not significant effect between (Egypt1, Egypt2) varieties by using hydrogel treatment were obtained at the (120\%) ETC treatment $(74.6,71.4)$. These results are in harmony with those obtained by (Shivani et al., 2001;Hassaan, 2003;Salem, 2005;Mohamed, 2007;Hefzy, 2009).

Biological yield kg per $\mathbf{m} 2$ : The results in table (12) indicate that Irrigation treatments and hydrogel treatment exerted a significant effect to biological yield obtained high values when increasing water and highest values when 
using hydrogel for the interaction between Irrigation treatments exerted a significant effect in biological yield in both seasons in (Egypt1, Egypt2) varieties respectively. The highest values obtained at (120\%) etc with hydrogel adding in the second season $(1.27,1.27) \mathrm{kg} / \mathrm{m} 2$ and the lowest values obtained at $(60 \%)$ etc without hydrogel adding in the first season $(0.88,0.77)$ $\mathrm{kg} / \mathrm{m} 2$. These results are in line with those obtained by (Almasian et al., 2006; Mohamed, 2007).

B.3. Grain yield /fed. (Ardab): These presented data in Table (13) show that Irrigation treatments and hydrogel treatment exerted a significant effect on wheat grain yield obtained high values when increasing water and the highest values when using hydrogel. In the first season at the $(60,80,100,120 \%)$ ETC obtained $(10.42,11.65,13.78,14.9)$ ardab to (Egypt1) variety respectively and $(9.07,11.48,14.6,15.06)$ ardab to (Egypt2) variety respectively while obtained $(10.7,12.15,14.51,15.4)$ ardab to (Egypt1) variety in the second season while obtained $(12.10,13.14,15.79,16.86)$ in the same variety but with out adding hydrogel .As for the (Egypt2) variety were obtained $(10.3,11.98,14.62,15.29)$ ardab without adding hydrogel while obtained(11.7,14.17,15.96,16.52) ardab with hydrogel adding, although this relationship is positive by increase irrigation water and hydrogel adding the grain yield increasing. These results are in harmony with those obtained by (Aly,2005;Mohamed 2007;Hefzy,2009).

B.4. 1000 - Grain weight (gm): The results in Table (14) and figure 7 indicate that the interaction between Irrigation treatments and hydrogel treatment exerted a significant effect to seed index and not significant in (Egypt1, Egypt2) varieties. The highest values of seed index obtained at 
(120\%) ETC (41.57, 40.28) respectively in the second season after adding hydrogel. These results in accordance with those obtained by (Shivani et al., 2001;Hassaan, 2003).

B.5. Straw yield per fed (ton): The results in table (15) indicate that Irrigation treatments and hydrogel treatment exerted a significant effect to straw yield obtained high values when increasing water and highest values when using hydrogel there for the interaction between Irrigation treatments exerted a significant effect in straw yield in both seasons in (Egypt1, Egypt2) varieties respectively. The highest values obtained at (120\%) etc with hydrogel adding in the second season $(3.36,3.42)$ ton and the lowest values obtained at $(60 \%)$ etc without hydrogel adding in the first season $(2.13,2.34)$ ton. These results are in line with those obtained by (Almasian et al., 2006; Mohamed ,2007;Hefzy, 2009).

B.6. Harvest index (H. I): The data in table (16) reveal that Irrigation treatments maybe exerted a significant effect or no exerted to harvest index but hydrogel adding exerted a significant effect. These results are in harmony with those obtained by (Rayan et al., 2000;Khalil et al., 2006;Mohamed, 2007;Hefzy, 2009). 
Table (7): Effect of different irrigation treatments and hydrogel on days to heading. to (Egypt1, Egypt2) varieties

\begin{tabular}{|c|c|c|c|c|c|c|c|}
\hline \multirow{2}{*}{\multicolumn{2}{|c|}{ Factor }} & \multirow{2}{*}{\multicolumn{2}{|c|}{\begin{tabular}{|l|}
$2013 / 14$ \\
Variety
\end{tabular}}} & \multirow{3}{*}{ Mean } & \multirow{2}{*}{\multicolumn{2}{|c|}{$\begin{array}{l}2014 / 15 \\
\text { Variety } \\
\end{array}$}} & \multirow{3}{*}{ Mean } \\
\hline & & & & & & & \\
\hline Irrigation & Hydrogel & Misr 1 & $\begin{array}{l}\text { Misr } \\
2\end{array}$ & & Misr 1 & Misr 2 & \\
\hline \multirow{3}{*}{$60 \%$} & with & - & - & - & 49.80 & 49.40 & 49.60 \\
\hline & control & 42.8 & 42.6 & 42.7 & 42.60 & 42.80 & 42.70 \\
\hline & & 42.8 & 42.6 & 42.7 & 46.20 & 46.10 & 46.15 \\
\hline \multirow{3}{*}{$80 \%$} & with & - & - & - & 55.20 & 54.40 & 54.80 \\
\hline & control & 49.4 & 49.4 & 49.4 & 45.40 & 45.20 & 45.30 \\
\hline & & 49.4 & 49.4 & 49.4 & 50.30 & 49.80 & 50.05 \\
\hline \multirow{3}{*}{$100 \%$} & with & - & - & - & 58.60 & 58.40 & 58.50 \\
\hline & control & 57 & 56.6 & 56.8 & 55.80 & 56.20 & 56.00 \\
\hline & & 57 & 56.6 & 56.8 & 57.20 & 57.30 & 57.25 \\
\hline \multirow{3}{*}{$120 \%$} & with & - & - & - & 60.40 & 60.80 & 60.60 \\
\hline & control & 58.2 & 58.6 & 58.4 & 59.00 & 59.00 & 59.00 \\
\hline & & 58.2 & 58.6 & 58.4 & 59.70 & 59.90 & 59.80 \\
\hline \multicolumn{2}{|c|}{ Mean } & 51.85 & 51.8 & 51.83 & 53.35 & 53.28 & 53.31 \\
\hline \multirow{3}{*}{\multicolumn{2}{|c|}{ LSD 0.05}} & \multicolumn{3}{|c|}{$\begin{array}{c}1=3.12 \quad V=N S \\
I \times V=N S\end{array}$} & $\mathrm{I}=1.26$ & $\begin{array}{l}\mathrm{H}= \\
1.09\end{array}$ & $\begin{array}{l}\mathrm{V}= \\
2.18\end{array}$ \\
\hline & & \multirow{2}{*}{\multicolumn{3}{|c|}{$\begin{array}{c}\text { I=IRRIGATION } \\
\text { H=HYDROGEL } \\
\text { V=VARIETY }\end{array}$}} & $\begin{array}{c}\mathrm{I} \times \mathrm{H}= \\
\mathrm{NS}\end{array}$ & $\begin{array}{c}\mathrm{I} \times \mathrm{V}= \\
\mathrm{NS}\end{array}$ & $\begin{array}{c}\mathrm{H} \times \mathrm{V}= \\
\mathrm{NS}\end{array}$ \\
\hline & & & & & & $\mathrm{H} \times \mathrm{V}=$ & \\
\hline
\end{tabular}


J. Environ. Sci.

Institute of Environmental Studies and Research - Ain Shams University

Table (8): Effect of different irrigation treatments and hydrogel on plant heightto (Egypt1, Egypt2) varieties

\begin{tabular}{|c|c|c|c|c|c|c|c|}
\hline \multirow{2}{*}{\multicolumn{2}{|c|}{ Factor }} & \multirow{2}{*}{\multicolumn{2}{|c|}{$\begin{array}{l}2013 / 14 \\
\text { Variety }\end{array}$}} & \multirow{3}{*}{ Mean } & \multirow{2}{*}{\multicolumn{2}{|c|}{$\begin{array}{l}2014 / 15 \\
\text { Variety }\end{array}$}} & \multirow{3}{*}{ Mean } \\
\hline & & & & & & & \\
\hline Irrigation & Hydrogel & Misr 1 & $\begin{array}{c}\text { Misr } \\
2\end{array}$ & & Misr 1 & Misr 2 & \\
\hline \multirow{3}{*}{$60 \%$} & with & - & - & - & 85.60 & 85.50 & 85.55 \\
\hline & control & 85.2 & 86.0 & 85.6 & 84.20 & 85.40 & 84.80 \\
\hline & & 85.2 & 86.0 & 85.6 & 84.90 & 85.45 & 85.18 \\
\hline \multirow{3}{*}{$80 \%$} & with & - & - & - & 88.70 & 86.70 & 87.70 \\
\hline & control & 85.1 & 84.9 & 85 & 85.60 & 84.80 & 85.20 \\
\hline & & 85.1 & 84.9 & 85 & 87.15 & 85.75 & 86.45 \\
\hline \multirow{3}{*}{$100 \%$} & with & - & - & - & 93.10 & 93.90 & 93.50 \\
\hline & control & 93.6 & 93.7 & 93.65 & 91.50 & 90.90 & 91.20 \\
\hline & & 93.6 & 93.7 & 93.65 & 92.30 & 92.40 & 92.35 \\
\hline \multirow{3}{*}{$120 \%$} & with & - & - & - & 98.80 & 97.80 & 98.30 \\
\hline & control & 95.2 & 97.7 & 96.45 & 92.00 & 91.60 & 91.80 \\
\hline & & 95.2 & 97.7 & 96.45 & 95.40 & 94.70 & 95.05 \\
\hline \multicolumn{2}{|c|}{ Mean } & 89.77 & 90.58 & 90.18 & 89.94 & 89.58 & 89.76 \\
\hline \multirow{3}{*}{\multicolumn{2}{|c|}{ LSD 0.05}} & \multirow{3}{*}{\multicolumn{3}{|c|}{$\begin{array}{c}1=4.45 \quad \mathrm{~V}=\mathrm{NS} \\
\mathrm{I} \times \mathrm{V}=\mathrm{NS}\end{array}$}} & $\mathrm{I}=3.8$ & $\begin{array}{l}\mathrm{H}= \\
2.04\end{array}$ & $\mathrm{~V}=\mathrm{NS}$ \\
\hline & & & & & $\mathrm{I} \times \mathrm{H}=\mathrm{NS}$ & $\begin{array}{l}\text { I } x \mathrm{~V} \\
=\mathrm{NS}\end{array}$ & $\begin{array}{c}\mathrm{H} \times \mathrm{V}= \\
\mathrm{NS}\end{array}$ \\
\hline & & & & & \multicolumn{3}{|c|}{$\mathrm{I} \times \mathrm{H} \times \mathrm{V}=\mathrm{NS}$} \\
\hline
\end{tabular}


Table(9): Effect of different irrigation treatments and hydrogel on spike length $(\mathrm{cm})$ to (Egypt1, Egypt2) varieties

\begin{tabular}{|c|c|c|c|c|c|c|c|}
\hline \multirow{2}{*}{\multicolumn{2}{|c|}{ Factor }} & \multirow{2}{*}{\multicolumn{2}{|c|}{\begin{tabular}{|l|}
$2013 / 14$ \\
Variety
\end{tabular}}} & \multirow{3}{*}{ Mean } & \multirow{2}{*}{\multicolumn{2}{|c|}{$\begin{array}{l}2014 / 15 \\
\text { Variety }\end{array}$}} & \multirow{3}{*}{ Mean } \\
\hline & & & & & & & \\
\hline Irrigation & Hydrogel & $\begin{array}{c}\text { Misr } \\
1\end{array}$ & $\begin{array}{c}\text { Misr } \\
2\end{array}$ & & Misr 1 & Misr 2 & \\
\hline \multirow{3}{*}{$60 \%$} & with & - & - & - & 10.10 & 9.40 & 9.75 \\
\hline & control & 9.2 & 9.3 & 9.25 & 9.20 & 8.70 & 8.95 \\
\hline & & 9.2 & 9.3 & 9.25 & 9.65 & 9.05 & 9.35 \\
\hline \multirow{3}{*}{$80 \%$} & with & - & - & - & 11.30 & 11.00 & 11.15 \\
\hline & control & 10.6 & 10.7 & 10.65 & 10.00 & 10.90 & 10.45 \\
\hline & & 10.6 & 10.7 & 10.65 & 10.65 & 10.95 & 10.80 \\
\hline \multirow{3}{*}{$100 \%$} & with & - & - & - & 11.40 & 11.40 & 11.40 \\
\hline & control & 10.8 & 11.1 & 10.95 & 10.50 & 10.60 & 10.55 \\
\hline & & 10.8 & 11.1 & 10.95 & 10.95 & 11.00 & 10.98 \\
\hline \multirow{3}{*}{$120 \%$} & with & - & - & - & 12.10 & 12.30 & 12.20 \\
\hline & control & 12.1 & 11.4 & 11.75 & 11.90 & 12.20 & 12.05 \\
\hline & & 12.1 & 11.4 & 11.75 & 12.00 & 12.25 & 12.13 \\
\hline \multicolumn{2}{|c|}{ Mean } & 10.68 & 10.63 & 10.65 & 10.80 & 10.81 & 10.81 \\
\hline \multirow{3}{*}{\multicolumn{2}{|c|}{ LSD 0.05}} & \multirow{3}{*}{\multicolumn{3}{|c|}{$\begin{array}{c}1=1.49 \quad \mathrm{~V}=\mathrm{NS} \\
\mathrm{I} \times \mathrm{V}=\mathrm{NS}\end{array}$}} & $\mathrm{I}=1.14$ & $\begin{array}{l}\mathrm{H}= \\
055 \\
\end{array}$ & $\begin{array}{l}\mathrm{V}= \\
\mathrm{NS}\end{array}$ \\
\hline & & & & & $\mathrm{I} \times \mathrm{H}=\mathrm{NS}$ & $\begin{array}{c}\mathrm{I} \times \mathrm{V}= \\
\mathrm{NS}\end{array}$ & $\begin{array}{l}\mathrm{H} \times \mathrm{V} \\
=\mathrm{NS}\end{array}$ \\
\hline & & & & & $\mathrm{Ix}$ & $\mathrm{xV}=\mathrm{NS}$ & \\
\hline
\end{tabular}


J. Environ. Sci.

Institute of Environmental Studies and Research - Ain Shams University

Table (10): effect of different irrigation treatments and hydrogel on no of spikes / m2 to (Egypt1, Egypt2) varieties

\begin{tabular}{|c|c|c|c|c|c|c|c|}
\hline \multirow{2}{*}{\multicolumn{2}{|c|}{ Factor }} & \multirow{2}{*}{\multicolumn{2}{|c|}{\begin{tabular}{|l|}
$2013 / 14$ \\
Variety
\end{tabular}}} & \multirow{3}{*}{ Mean } & \multirow{2}{*}{\multicolumn{2}{|c|}{$\begin{array}{l}\text { 2014/15 } \\
\text { Variety } \\
\end{array}$}} & \multirow{3}{*}{ Mean } \\
\hline & & & & & & & \\
\hline Irrigation & Hydrogel & $\begin{array}{c}\text { Misr } \\
1\end{array}$ & $\begin{array}{c}\text { Misr } \\
2\end{array}$ & & Misr 1 & Misr 2 & \\
\hline \multirow{3}{*}{$60 \%$} & with & 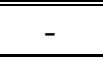 & - & - & 353.60 & 370.40 & 362.00 \\
\hline & control & 301 & 335.2 & 318.1 & 331.40 & 323.80 & 327.60 \\
\hline & & 301 & 335.2 & 318.1 & 342.50 & 347.10 & 344.80 \\
\hline \multirow{3}{*}{$80 \%$} & with & - & - & - & 400.00 & 416.20 & 408.10 \\
\hline & control & 354.4 & 362.4 & 358.4 & 364.20 & 363.00 & 363.60 \\
\hline & & 354.4 & 362.4 & 358.4 & 382.10 & 389.60 & 385.85 \\
\hline \multirow{3}{*}{$100 \%$} & with & - & - & - & 439.20 & 444.20 & 441.70 \\
\hline & control & 396 & 396.2 & 393.1 & 390.40 & 393.20 & 391.80 \\
\hline & & 396 & 396.2 & 393.1 & 414.80 & 418.70 & 416.75 \\
\hline \multirow{3}{*}{$120 \%$} & with & - & - & - & 452.40 & 453.40 & 452.90 \\
\hline & control & 420.6 & 422.2 & 421.4 & 417.80 & 423.40 & 420.60 \\
\hline & & 420.6 & 422.2 & 421.4 & 435.10 & 438.40 & 436.75 \\
\hline \multicolumn{2}{|c|}{ Mean } & 368 & 377.50 & 372.8 & 393.63 & 398.45 & 396.04 \\
\hline \multirow{3}{*}{\multicolumn{2}{|c|}{ LSD 0.05}} & \multirow{3}{*}{\multicolumn{3}{|c|}{$\begin{array}{c}1=1.49 \quad \mathrm{~V}=\mathrm{NS} \\
\mathrm{I} \times \mathrm{V}=\mathrm{NS}\end{array}$}} & $\begin{array}{c}I= \\
23.59\end{array}$ & $\begin{array}{c}\mathrm{H}= \\
21.61\end{array}$ & $\begin{array}{l}\mathrm{V}= \\
\mathrm{NS}\end{array}$ \\
\hline & & & & & $\begin{array}{c}\mathrm{I} \times \mathrm{H}= \\
\mathrm{NS}\end{array}$ & $\begin{array}{c}\mathrm{I} \times \mathrm{V}= \\
\mathrm{NS}\end{array}$ & $\begin{array}{l}\mathrm{H} \times \mathrm{V} \\
=\mathrm{NS}\end{array}$ \\
\hline & & & & & \multicolumn{3}{|c|}{$\mathrm{I} \times \mathrm{H} \times \mathrm{V}=\mathrm{NS}$} \\
\hline
\end{tabular}


Table (11): Effect of different irrigation treatments and hydrogel on no of grains / spike to (Egypt1, Egypt2) varieties

\begin{tabular}{|c|c|c|c|c|c|c|c|}
\hline \multirow{2}{*}{\multicolumn{2}{|c|}{ Factor }} & \multirow{2}{*}{\multicolumn{2}{|c|}{$\begin{array}{l}2013 / 14 \\
\text { Variety }\end{array}$}} & \multirow{3}{*}{ Mean } & \multirow{2}{*}{\multicolumn{2}{|c|}{\begin{tabular}{|l|}
$2014 / 15$ \\
Variety
\end{tabular}}} & \multirow{3}{*}{ Mean } \\
\hline & & & & & & & \\
\hline Irrigation & Hydrogel & $\underset{1}{\operatorname{Misr}}$ & $\underset{2}{\text { Misr }}$ & & Misr 1 & Misr 2 & \\
\hline \multirow{3}{*}{$60 \%$} & with & - & - & - & 56.80 & 55.00 & 55.90 \\
\hline & control & 44 & 46.2 & 45.1 & 49.20 & 43.20 & 46.20 \\
\hline & & 44 & 46.2 & 45.1 & 53.00 & 49.10 & 51.05 \\
\hline \multirow{3}{*}{$80 \%$} & with & - & - & - & 66.80 & 64.20 & 65.50 \\
\hline & control & 50 & 50.48 & 50.24 & 52.08 & 53.00 & 52.54 \\
\hline & & 50 & 50.48 & 50.24 & 59.44 & 58.60 & 59.02 \\
\hline \multirow{3}{*}{$100 \%$} & with & - & - & - & 70.60 & 71.60 & 71.10 \\
\hline & control & 64.6 & 64 & 64.3 & 62.60 & 63.60 & 63.10 \\
\hline & & 64.6 & 64 & 64.3 & 66.60 & 67.60 & 67.10 \\
\hline \multirow{3}{*}{$120 \%$} & with & - & - & - & 74.60 & 71.40 & 73.00 \\
\hline & control & 64.4 & 66.6 & 65.5 & 65.00 & 63.20 & 64.10 \\
\hline & & 64.4 & 66.6 & 65.5 & 69.80 & 67.30 & 68.55 \\
\hline \multicolumn{2}{|c|}{ Mean } & 55.75 & 56.82 & 56.29 & 62.21 & 60.65 & 61.43 \\
\hline \multirow{3}{*}{\multicolumn{2}{|c|}{$\operatorname{LSD}_{0.05}$}} & \multirow{3}{*}{\multicolumn{3}{|c|}{$\begin{array}{c}1=9.64 \quad V=N S \\
I \times V=N S\end{array}$}} & $\mathrm{I}=4.42$ & $\begin{array}{l}\mathrm{H}= \\
3.36 \\
\end{array}$ & $\begin{array}{l}\mathrm{V}= \\
\mathrm{NS}\end{array}$ \\
\hline & & & & & $\mathrm{I} \times \mathrm{H}=\mathrm{NS}$ & $\begin{array}{c}\mathrm{I} \times \mathrm{V}= \\
\mathrm{NS}\end{array}$ & $\begin{array}{l}\mathrm{H} \times \mathrm{V} \\
=\mathrm{NS}\end{array}$ \\
\hline & & & & & I x H & $\times \mathrm{V}=\mathrm{N}$ & \\
\hline
\end{tabular}


J. Environ. Sci.

Institute of Environmental Studies and Research - Ain Shams University

Table(12): Effect of different irrigation treatments and hydrogel on biological yield kg per m2 to (Egypt1, Egypt2) varieties

\begin{tabular}{|c|c|c|c|c|c|c|c|}
\hline \multirow{2}{*}{\multicolumn{2}{|c|}{ Factor }} & \multirow{2}{*}{\multicolumn{2}{|c|}{$\begin{array}{c}2013 / 14 \\
\text { Variety } \\
\end{array}$}} & \multirow{3}{*}{ Mean } & \multirow{2}{*}{\multicolumn{2}{|c|}{$\begin{array}{l}2014 / 15 \\
\text { Variety } \\
\end{array}$}} & \multirow{3}{*}{ Mean } \\
\hline & & & & & & & \\
\hline Irrigation & Hydrogel & $\begin{array}{c}\text { Misr } \\
1\end{array}$ & $\begin{array}{c}\text { Misr } \\
2\end{array}$ & & Misr 1 & Misr 2 & \\
\hline \multirow{3}{*}{$60 \%$} & with & - & - & - & 1.03 & 1.00 & 1.01 \\
\hline & control & 0.88 & 0.77 & 0.83 & 0.89 & 0.87 & 0.88 \\
\hline & & 0.88 & 0.77 & 0.83 & 0.96 & 0.93 & 0.95 \\
\hline \multirow{3}{*}{$80 \%$} & with & - & - & - & 1.12 & 1.22 & 1.17 \\
\hline & control & 0.97 & 0.97 & 0.97 & 1.05 & 0.98 & 1.01 \\
\hline & & 0.97 & 0.97 & 0.97 & 1.09 & 1.10 & 1.09 \\
\hline \multirow{3}{*}{$100 \%$} & with & - & - & - & 1.33 & 1.35 & 1.34 \\
\hline & control & 1.13 & 1.15 & 1.14 & 1.22 & 1.22 & 1.22 \\
\hline & & 1.13 & 1.15 & 1.14 & 1.28 & 1.28 & 1.28 \\
\hline \multirow{3}{*}{$120 \%$} & with & - & - & - & 1.41 & 1.40 & 1.41 \\
\hline & control & 1.23 & 1.26 & 1.25 & 1.27 & 1.27 & 1.27 \\
\hline & & 1.23 & 1.26 & 1.25 & 1.34 & 1.34 & 1.34 \\
\hline \multicolumn{2}{|c|}{ Mean } & 1.05 & 1.04 & 1.05 & 1.16 & 1.16 & 1.16 \\
\hline \multirow{3}{*}{\multicolumn{2}{|c|}{ LSD 0.05}} & \multirow{3}{*}{\multicolumn{3}{|c|}{$\begin{array}{c}1=0.12 \quad \mathrm{~V}=\mathrm{NS} \\
\mathrm{I} \times \mathrm{V}=\mathrm{NS}\end{array}$}} & $\mathrm{I}=0.11$ & $\begin{array}{c}\mathrm{H} \\
=0.05\end{array}$ & $\begin{array}{l}\mathrm{V}= \\
\mathrm{NS}\end{array}$ \\
\hline & & & & & $\mathrm{I} \times \mathrm{H}=\mathrm{NS}$ & $\begin{array}{c}\mathrm{I} \times \mathrm{V}= \\
\mathrm{NS}\end{array}$ & $\begin{array}{l}\mathrm{H} \times \mathrm{V} \\
=\mathrm{NS}\end{array}$ \\
\hline & & & & & $\mathrm{Ix} \mathrm{H}$ & $x \mathrm{~V}=\mathrm{N}$ & \\
\hline
\end{tabular}


Table(13): Effect of different irrigation treatments and hydrogel on grain yield / fed (ardab) to (Egypt1, Egypt2) varieties

\begin{tabular}{|c|c|c|c|c|c|c|c|}
\hline \multirow{2}{*}{\multicolumn{2}{|c|}{ Factor }} & \multirow{2}{*}{\multicolumn{2}{|c|}{\begin{tabular}{|l|}
$2013 / 14$ \\
Variety
\end{tabular}}} & \multirow{3}{*}{ Mean } & \multirow{2}{*}{\multicolumn{2}{|c|}{$\begin{array}{l}2014 / 15 \\
\text { Variety }\end{array}$}} & \multirow{3}{*}{ Mean } \\
\hline & & & & & & & \\
\hline Irrigation & Hydrogel & Misr 1 & Misr 2 & & Misr 1 & Misr 2 & \\
\hline \multirow{3}{*}{$60 \%$} & with & - & - & - & 12.10 & 11.70 & 11.90 \\
\hline & control & 10.42 & 9.07 & 9.74 & 10.70 & 10.30 & 10.50 \\
\hline & & 10.42 & 9.07 & 9.74 & 11.40 & 11.00 & 11.20 \\
\hline \multirow{3}{*}{$80 \%$} & with & - & - & - & 13.44 & 14.17 & 13.80 \\
\hline & control & 11.65 & 11.48 & 11.56 & 12.15 & 11.98 & 12.07 \\
\hline & & 11.65 & 11.48 & 11.56 & 12.80 & 13.08 & 12.94 \\
\hline \multirow{3}{*}{$100 \%$} & with & - & - & - & 15.79 & 15.96 & 15.88 \\
\hline & control & 13.78 & 10.06 & 13.92 & 14.51 & 14.62 & 14.56 \\
\hline & & 13.78 & 10.06 & 13.92 & 15.15 & 15.29 & 15.22 \\
\hline \multirow{3}{*}{$120 \%$} & with & - & - & - & 16.86 & 16.52 & 16.69 \\
\hline & control & 14.9 & 15.06 & 14.98 & 15.40 & 15.29 & 15.34 \\
\hline & & 14.9 & 15.06 & 14.98 & 16.13 & 15.90 & 16.02 \\
\hline \multicolumn{2}{|c|}{ Mean } & 12.68 & 12.42 & 12.55 & 13.87 & 13.82 & 13.84 \\
\hline \multirow{3}{*}{\multicolumn{2}{|c|}{$\operatorname{LSD}_{0.05}$}} & \multirow{3}{*}{\multicolumn{3}{|c|}{$\begin{array}{c}1=1.64 \quad V=N S \\
I x V=N S\end{array}$}} & $\mathrm{I}=1.24$ & $\begin{aligned} & \mathrm{H} \\
= & 0.63\end{aligned}$ & $\begin{array}{l}\mathrm{V}= \\
\mathrm{NS}\end{array}$ \\
\hline & & & & & $\mathrm{I} \times \mathrm{H}=\mathrm{NS}$ & $\begin{array}{l}\text { I x V } \\
=\mathrm{NS}\end{array}$ & $\begin{array}{l}\mathrm{H} \times \mathrm{V} \\
=\mathrm{NS}\end{array}$ \\
\hline & & & & & \multicolumn{3}{|c|}{$\mathrm{I} \times \mathrm{H} \times \mathrm{V}=\mathrm{NS}$} \\
\hline
\end{tabular}


J. Environ. Sci.

Institute of Environmental Studies and Research - Ain Shams University

Table (14): Effect of different irrigation treatments and hydrogel on 1000grains weightto (Egypt1, Egypt2) varieties

\begin{tabular}{|c|c|c|c|c|c|c|c|}
\hline \multirow{2}{*}{\multicolumn{2}{|c|}{ Factor }} & \multirow{2}{*}{\multicolumn{2}{|c|}{\begin{tabular}{|l|}
$2013 / 14$ \\
Variety \\
\end{tabular}}} & \multirow{3}{*}{ Mean } & \multirow{2}{*}{\multicolumn{2}{|c|}{$\begin{array}{l}2014 / 15 \\
\text { Variety } \\
\end{array}$}} & \multirow{3}{*}{ Mean } \\
\hline & & & & & & & \\
\hline Irrigation & Hydrogel & $\begin{array}{c}\text { Misr } \\
1\end{array}$ & $\begin{array}{c}\text { Misr } \\
2 \\
\end{array}$ & & Misr 1 & Misr 2 & \\
\hline \multirow{3}{*}{$60 \%$} & with & - & - & - & 34.55 & 34.31 & 34.43 \\
\hline & control & 32.46 & 31.58 & 32.02 & 31.92 & 32.94 & 32.43 \\
\hline & & 32.46 & 31.58 & 32.02 & 33.23 & 33.63 & 33.43 \\
\hline \multirow{3}{*}{$80 \%$} & with & - & - & - & 35.92 & 36.14 & 36.03 \\
\hline & control & 34.53 & 33.47 & 34.0 & 33.53 & 35.47 & 34.50 \\
\hline & & 34.53 & 33.47 & 34.0 & 34.73 & 35.81 & 35.27 \\
\hline \multirow{3}{*}{$100 \%$} & with & - & - & - & 38.51 & 38.96 & 38.73 \\
\hline & control & 35.24 & 35.01 & 35.12 & 35.77 & 36.95 & 36.36 \\
\hline & & 35.24 & 35.01 & 35.12 & 37.14 & 37.95 & 37.55 \\
\hline \multirow{3}{*}{$120 \%$} & with & - & - & - & 41.57 & 40.28 & 40.93 \\
\hline & control & 37.11 & 36.6 & 36.85 & 36.98 & 37.03 & 37.01 \\
\hline & & 37.11 & 36.6 & 36.85 & 39.28 & 38.65 & 38.97 \\
\hline \multicolumn{2}{|c|}{ Mean } & 34.84 & 34.17 & 34.51 & 36.09 & 36.51 & 36.30 \\
\hline \multirow{3}{*}{\multicolumn{2}{|c|}{ LSD 0.05}} & \multirow{3}{*}{\multicolumn{3}{|c|}{$\begin{array}{c}1=1.71 \quad \mathrm{~V}=\mathrm{NS} \\
\mathrm{I} \times \mathrm{V}=\mathrm{NS}\end{array}$}} & $\mathrm{I}=2.02$ & $\begin{aligned} & \mathrm{H} \\
= & 1.11\end{aligned}$ & $\begin{array}{l}\mathrm{V}= \\
\mathrm{NS}\end{array}$ \\
\hline & & & & & $\mathrm{I} \times \mathrm{H}=\mathrm{NS}$ & $\begin{array}{c}\mathrm{I} \times \mathrm{V}= \\
\mathrm{NS}\end{array}$ & $\begin{array}{l}\mathrm{H} \times \mathrm{V} \\
=\mathrm{NS}\end{array}$ \\
\hline & & & & & $\mathrm{I} \times \mathrm{H}$ & $\mathrm{xV}=\mathrm{NS}$ & \\
\hline
\end{tabular}


Table(15): Effect of different irrigation treatments and hydrogel on straw yield per fed (ton) to (Egypt1, Egypt2) varieties

\begin{tabular}{|c|c|c|c|c|c|c|c|}
\hline \multirow{2}{*}{\multicolumn{2}{|c|}{ Factor }} & \multirow{2}{*}{\multicolumn{2}{|c|}{\begin{tabular}{|l|} 
2013/14 \\
Variety \\
\end{tabular}}} & \multirow{3}{*}{ Mean } & \multirow{2}{*}{\multicolumn{2}{|c|}{\begin{tabular}{l|}
$2014 / 15$ \\
Variety
\end{tabular}}} & \multirow{3}{*}{ Mean } \\
\hline & & & & & & & \\
\hline Irrigation & Hydrogel & Misr 1 & Misr 2 & & Misr 1 & Misr 2 & \\
\hline \multirow{3}{*}{$60 \%$} & with & - & - & - & 2.49 & 2.44 & 2.47 \\
\hline & control & 2.13 & 1.88 & 2.0 & 2.13 & 2.10 & 2.11 \\
\hline & & 2.13 & 1.88 & 2.0 & 2.31 & 2.27 & 2.29 \\
\hline \multirow{3}{*}{$80 \%$} & with & - & - & - & 2.70 & 2.98 & 2.84 \\
\hline & control & 2.31 & 2.34 & 2.33 & 2.58 & 2.31 & 2.44 \\
\hline & & 2.31 & 2.34 & 2.33 & 2.64 & 2.64 & 2.64 \\
\hline \multirow{3}{*}{$100 \%$} & with & - & - & - & 3.20 & 3.27 & 3.23 \\
\hline & control & 2.66 & 2.73 & 2.7 & 2.96 & 2.92 & 2.94 \\
\hline & & 2.66 & 2.73 & 2.7 & 3.08 & 3.09 & 3.09 \\
\hline \multirow{3}{*}{$120 \%$} & with & - & - & - & 3.39 & 3.42 & 3.40 \\
\hline & control & 2.91 & 3.02 & 2.97 & 3.01 & 3.06 & 3.03 \\
\hline & & 2.91 & 3.02 & 2.97 & 3.20 & 3.24 & 3.22 \\
\hline \multicolumn{2}{|c|}{ Mean } & 2.5 & 2.49 & 2.46 & 2.81 & 2.81 & 2.81 \\
\hline \multirow{3}{*}{\multicolumn{2}{|c|}{ LSD 0.05}} & \multirow{3}{*}{\multicolumn{3}{|c|}{$\begin{array}{c}1=0.42 \quad V=N S \\
I x V=N S\end{array}$}} & $\mathrm{I}=2.68$ & $\begin{aligned} & \mathrm{H} \\
= & 1.39\end{aligned}$ & $\begin{array}{l}\mathrm{V}= \\
\mathrm{NS}\end{array}$ \\
\hline & & & & & $\mathrm{I} \times \mathrm{H}=\mathrm{NS}$ & $\begin{array}{c}\mathrm{I} \times \mathrm{V}= \\
\mathrm{NS}\end{array}$ & $\begin{array}{l}\mathrm{H} \times \mathrm{V} \\
=\mathrm{NS}\end{array}$ \\
\hline & & & & & $\mathrm{Ix}$ & $x V=N$ & \\
\hline
\end{tabular}


Table(16): Effect of different irrigation treatments and hydrogel on harvest index (H. I) to (Egypt1, Egypt2) varieties

\begin{tabular}{|c|c|c|c|c|c|c|c|}
\hline \multirow{2}{*}{\multicolumn{2}{|c|}{ Factor }} & \multirow{2}{*}{\multicolumn{2}{|c|}{\begin{tabular}{|l|}
$2013 / 14$ \\
Variety \\
\end{tabular}}} & \multirow{3}{*}{ Mean } & \multirow{2}{*}{\multicolumn{2}{|c|}{\begin{tabular}{|l|}
$2014 / 15$ \\
Variety \\
\end{tabular}}} & \multirow{3}{*}{ Mean } \\
\hline & & & & & & & \\
\hline Irrigation & Hydro gel & $\underset{1}{\operatorname{Misr}}$ & $\begin{array}{c}\text { Misr } \\
2\end{array}$ & & $\underset{1}{\operatorname{Misr}}$ & $\begin{array}{c}\text { Misr } \\
2\end{array}$ & \\
\hline \multirow{3}{*}{$60 \%$} & with & - & - & - & 42.19 & 41.97 & 42.08 \\
\hline & control & 42.4 & 41.96 & 42.18 & 42.99 & 42.38 & 42.69 \\
\hline & & 42.4 & 41.96 & 42.18 & 42.59 & 42.18 & 42.38 \\
\hline \multirow{3}{*}{$80 \%$} & with & - & - & - & 42.72 & 41.59 & 42.16 \\
\hline & control & 43 & 42.44 & 42.72 & 41.45 & 43.81 & 42.63 \\
\hline & & 43 & 42.44 & 42.72 & 42.09 & 42.70 & 42.39 \\
\hline \multirow{3}{*}{$100 \%$} & with & - & - & - & 42.54 & 42.29 & 42.42 \\
\hline & control & 43.9 & 43.96 & 43.93 & 42.35 & 42.91 & 42.63 \\
\hline & & 43.9 & 43.96 & 43.93 & 42.44 & 42.60 & 42.52 \\
\hline \multirow{3}{*}{$120 \%$} & with & - & - & - & 42.75 & 42.00 & 42.38 \\
\hline & control & 43.46 & 42.91 & 43.19 & 43.48 & 42.89 & 43.18 \\
\hline & & 43.46 & 42.91 & 43.19 & 43.11 & 42.45 & 42.78 \\
\hline \multicolumn{2}{|c|}{ Mean } & 43.19 & 42.81 & 43 & 42.56 & 42.48 & 42.52 \\
\hline \multicolumn{2}{|c|}{$\operatorname{LSD}_{0.05}$} & \multicolumn{3}{|c|}{$\begin{array}{c}1=\mathrm{NS} \quad \mathrm{V}=\mathrm{NS} \\
\mathrm{I} \times \mathrm{V}=\mathrm{NS}\end{array}$} & $\mathrm{I}=\mathrm{NS}$ & $\mathrm{H}=048$ & $\mathrm{~V}=\mathrm{NS}$ \\
\hline
\end{tabular}

\section{REFERENCES}

Abd El-Mogied, S.E. (1990): Effect of some agricultural practices on growth and yield of wheat. M. Sc. Thesis, Fac. Agric., El-Minia Univ., Egypt.

Alazba AA (2001): Theoretical estimate of palm water requirements using Penman-Monteith model. ASAE Annual International Meeting. Paper no. 012100.

Allen, G. R.; Pereira, L. S.; Raes, D. and Smith, M. (1998): Crop evapotranspiration, guidelines for competing crop water requirements. FAO. Irrigation and drainages paper 56. Rome, Italy. 
Almasian, F, A. R. Astaraei and M.N. Mahallati (2006): Effect of leachate and solid waste compost on yield and yield components of wheat. J. Byaban, 11(1): 89-98.

Aly, A. S. (2005): Surge flow as development and management of irrigation efficiency in some soils of Fayoum. Ph.D. Fac. Agric El-Fayoum. Cairo Univ., Egypt.

Eid,H.M (1994): The impact of climate change to predict the productivity of wheat and maize in Egypt .

Eid,H.M., N.G. Ainer., S.M. El-Marsafawy and A.N. Khater (1999): Crop water needs under different irrigation systems in the new lands. The 3rd Conf. on-Farm Irrigation and Agroclimatology, paper No. 52, pp. 691-703.

Elmaloglou S, Diamantopoulos E. (2007): Wetting front advance patterns and water losses by deep percolation under the root zone as influenced by pulsed drip irrigation. Agriculture Water Management 90: 160163. Links.

Elmaloglou S, Diamantopoulos E. (2009): Simulation of soil water dynamics under drip irrigation from line sources. Agriculture Water Management. 96: 1587-595.

El- Sayed, M. A. A., (2003): Response of wheat to irrigation in sandy soils. zagazig J. Agric. Res., 30 (1) : 1-15.

Golam, M. and S.B. Goswami, (2004): Response of wheat to water deficit and foliar spray of urea and potassium sulphate. Indian J. of Plant Physiology., 9(2): 212-215. (C.F. Computer Research).

Hefzy, M.M.A (2009): Water requirements for som crops grown on newly reclaimed soils of Assiut Governorate. M.Sc. Fac. Agric., Assiut, Univ. Egypt.

Khalil, F. A. F.; Tammam, A. M. Amin I. M. and Mohamed, K. A.(2006): Scheduling irrigation for some wheat cultivars under upper Egypt condition. J. Agric. Sci. Mansoura Univ., 31(1) : 561- 572. 
Mohamed, K. A. and Tammam, A. M. (1999): Drought resistance of some wheat varieties in Upper Egypt. Third Conf. on Farm Irrigation and Agroclimatology Programme and Abstracts. January 25-27, Giza, Egypt.

Mohamed, M. M. E.(2007): Water requirement of wheat and sunflower under different irrigation system at Assiut. M.Sc. Fac. Agric.,Assiut, Univ. Egypt.

Moussa,A. M. and Abdel - maksoud H. H.(2004): Effect of soil moisture regime on yield and its components and water use efficiency for some wheat cultivars. Annalas Agric. Sci., Ain Shams Univ., Cairo, 49(2): 515-530.

Rayan,A.A.; S.M. El-Marshafawy and N. G. Ainer and S.E. Soliman. (2000): Schedule irrigation of wheat crop in Upper Egypt under some sowing dates. Egypt. J. Appl. Sci., 15(1): 10-23.

Salem, M.A. (2005): Effect of nitrogen rates and irrigation regimes on yield and yield components of bread wheat (Triticum aestivum L.)genot ypes under newly reclaimed land conditions. J. Agric. Sci., Mansoura Univ., Egypt, 30(11): 6481-6490.

Shivani, U.N. Verma, S.K. Pal, R. Thakur and S. Kumar (2001):Production P roduction potential and water-use efficiency of wheat (Triticum aestivum) cultivars under different dates of seeding and irrigation levels. Indian J. Agron., 46(4): 659-664.

Simonne, E., D. Studstill, R.,C. Hochmuth.(2006): Understanding water movement in mulched beds on sandy soils: an approach to ecologically sound fertigation in vegetable production. International Society for Horticultural Science. online search.

Smith, N. (1991): CROPWAT model for ETo calculation using penman monteith method. FAO.

Vites, F. G. (1965): Increasing water use efficiency by soil management. America Society Agronomy, Madison, Wisconsin, p. 259-274.

Zazueta, F. S. and Smajstrala, A. G. (1984): Evapotranspiration estimation utilities water model. Agricultural Engineering department, IFAS, Univ. of Florida Gainesville, Florida. 


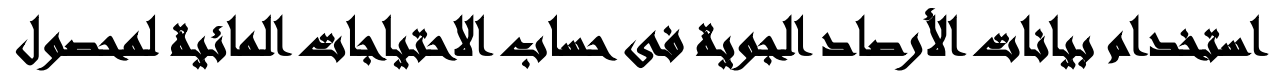

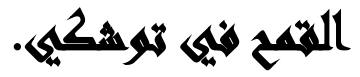

[

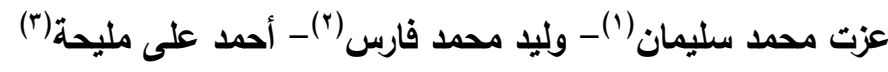

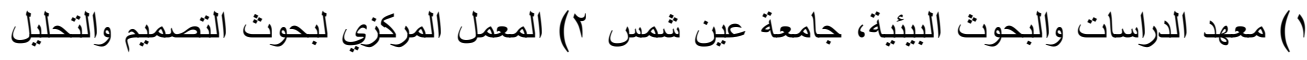

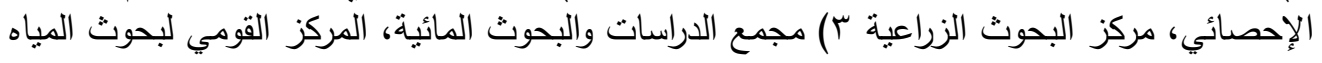

\section{المستخلص}

أجريت هذه الدراسة في مزرعة تجارب الأبحاث الزراعية بمجمع الدراسات والبحوث المائية

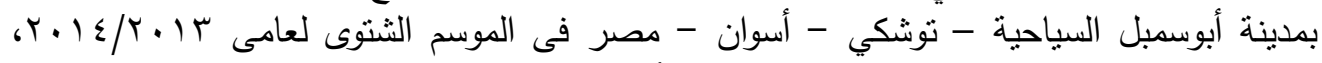

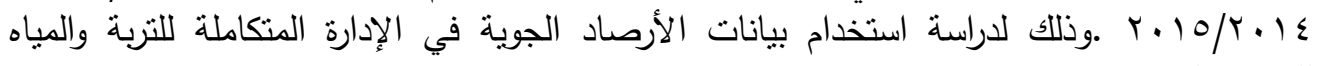

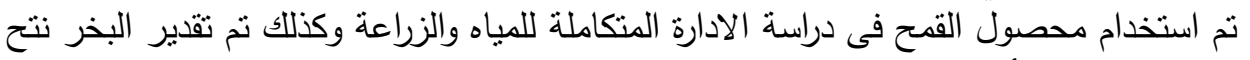

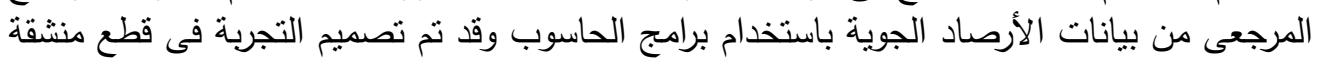

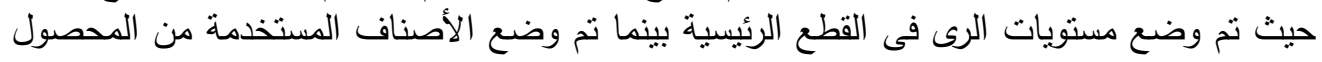
المنزرع فى القطع الفرعية.

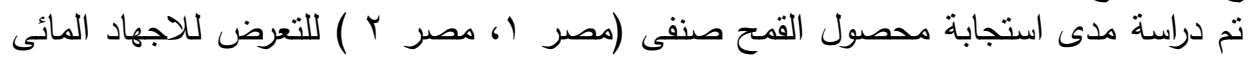

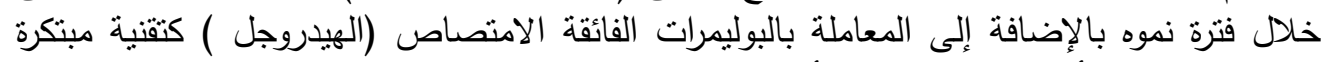

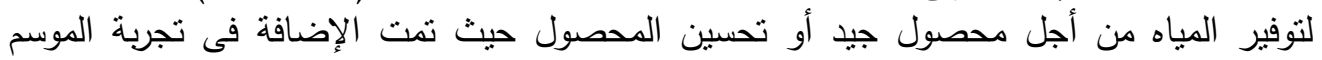

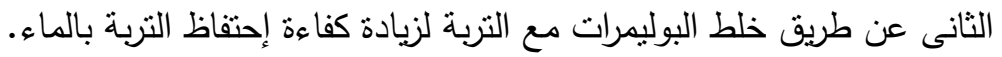

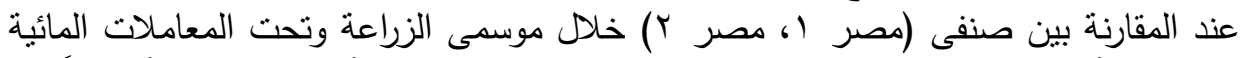

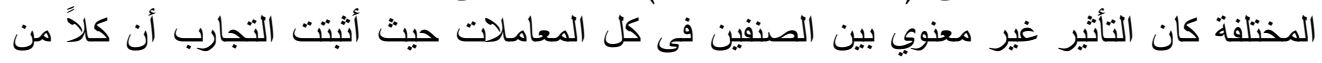

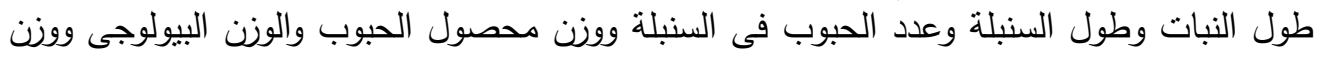

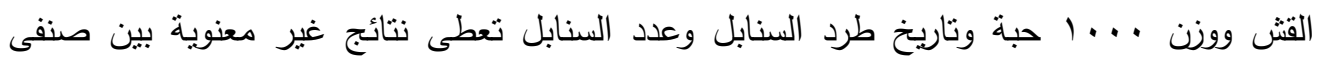

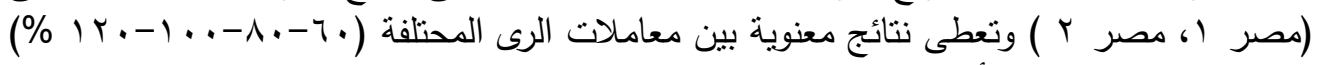

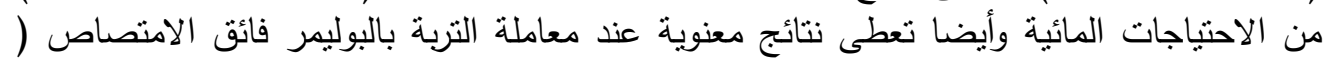

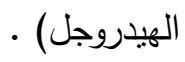




\section{التوصيات العامة: - ات}

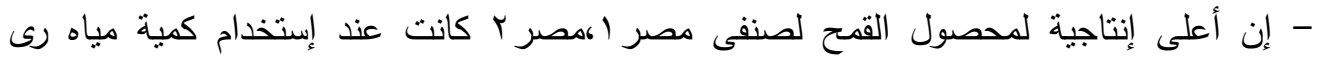

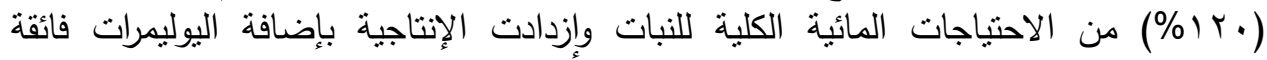

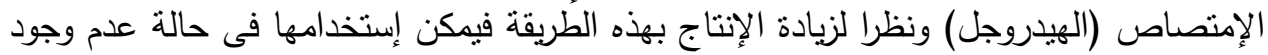

$$
\text { مشكلة فى وفرة المياه. }
$$

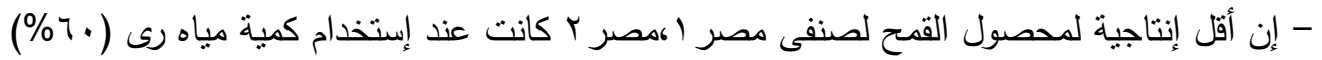

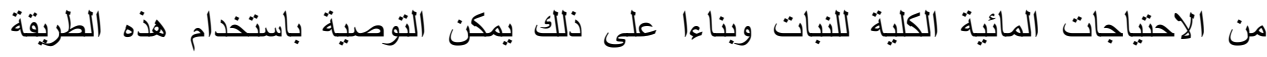

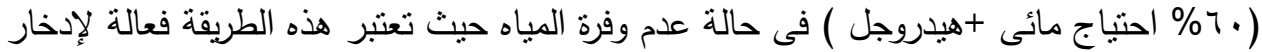

- إن خفض مياه الرى يعتبر واحد من أهم الاستيراتيجيات المقترحة الآن من أجل مواجهة أزمة ندرة

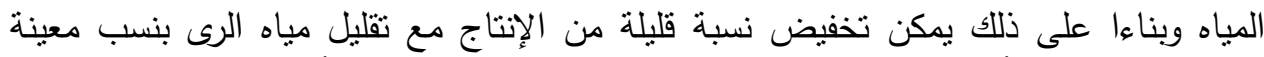

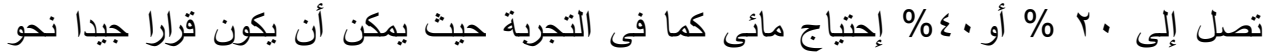

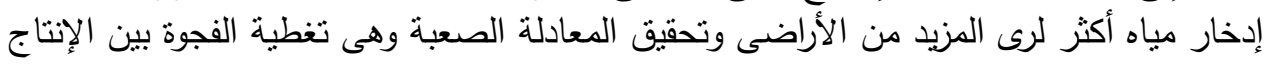

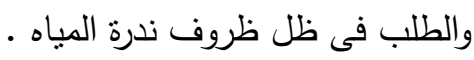

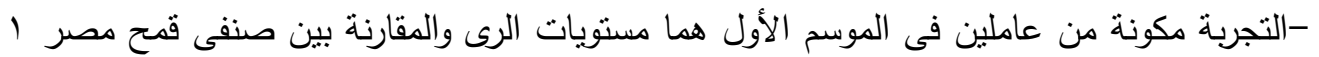

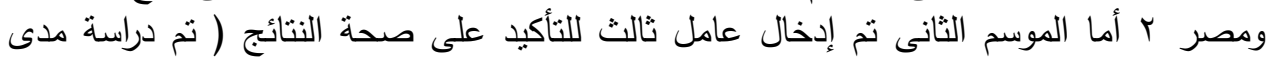

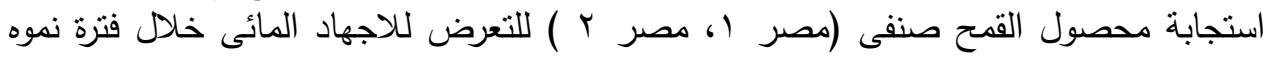
بالإضافة إلى المعاملة بالبوليمرات الفائقة الامتصاص (العيدروجل ) كثقنية مبتكرة لتوفير المياه

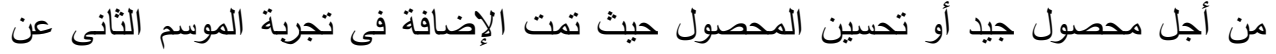

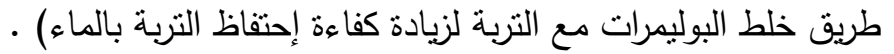

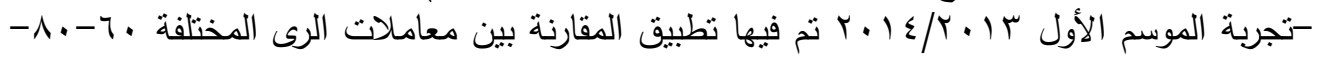

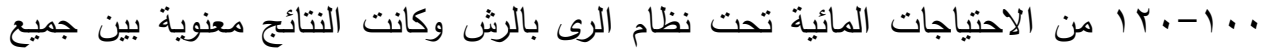

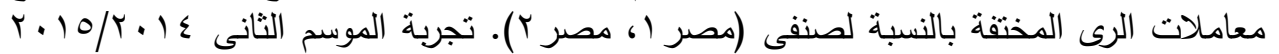

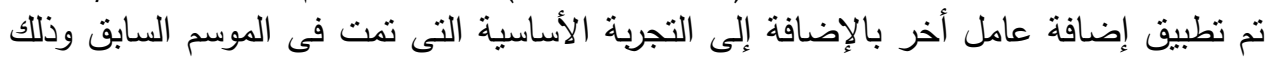

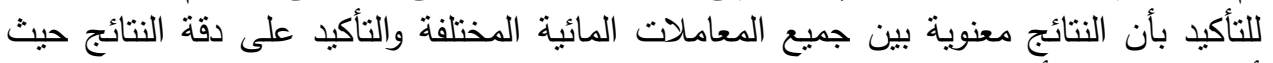

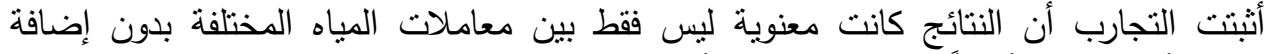

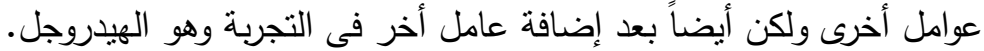

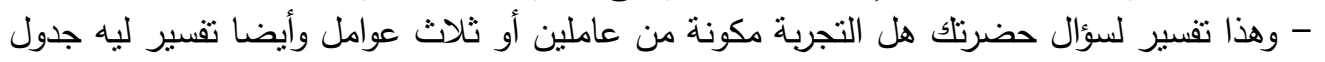

$$
\text { رقم } 0 \text { يختلف عن جدول رقم } 7 .
$$

